\title{
Higher Energy Prices And Resource Endowments In An Export Base Model Context
}

\author{
David P. Manuel*
}

The comparatively recent era of higher energy prices has spurred much work on aggregate economic effects of energy price escalations. Results of such work have been wide-ranging, including the contributions of higher energy prices to national recessions [Mork and Hall 1980], accounting for energy prices in recent inflation [Mork and Hall 1980], and the stimulus of higher energy prices to factor substitutions [Griffin and Gregory 1976; Field and Grebenstein 1980]. Relatively little work, however, has been undertaken to investigate the impacts of higher energy prices on regional income and employment.

Soon after the 1973-1974 Arab oil embargo, Miernyk advanced the hypothesis that higher energy prices in the United States would result in income increasing more rapidly in regions (states) which produce energy than in regions which do not [Miernyk 1975, 1976, 1977] The foundation of Miernyk's hypothesis rests on the elimination of two consequences of low energy prices. Historically, low domestic energy prices were due to a variety of market and nonmarket conditions, therefore, consumers enjoyed a consumer surplus. In addition producers of non-energy goods reaped the benefits of low energy prices relative to other intermediate production inputs and thereby realized economic rents [Miernyk 1976, pp. 213-214]. This paper presents an analysis of real state per capita personal income growth rates in the five years prior to and following the embargo to determine if Miernyk's observation is valid.

To test the hypothesis a variant of the export base model is used to explain per capita income growth. Miernyk's original hypothesis was based on the distinction between energy producing and energy consuming states [Miernyk 1975, 1976, 1977]. Despite the validity of the hypothesis, an explicit definition of each group was not presented. Since the export base model presumes that trade between regions is the prime generator of economic growth, a definition which captures the trading of surplus energy production is necessary. To test Miernyk's hypothesis, this paper employs Chase Econometrics' definition of energy surplus and energy deficit states [Corrigan and Stanfield 1980, p. 469]. 
Earlier work has shown that export base employment growth is positively correlated with per capita income growth [Luttrell and Gray 1970]. In this paper slight modifications are made to the basic model by including several dummy variables which distinguish between energy surplus and deficit states, sunbelt and non sunbelt states, and the pre embargo years from post embargo years.

Two sections follow. Miernyk's hypothesis is examined in detail as well as the appropriateness of the export base model. The following section also delimits certain definitions which are important for testing purposes. In the last section empirical results are presented and evaluated.

\section{MIERNYK'S HYPOTHESIS` ${ }^{1}$ AND THE MODEL}

At the center of Miernyk's hypothesis is the elimination of consumers' surpluses and producers' economic rents. However, higher energy prices and energy resource endowments per se would not appear to be sufficient conditions to cause per capita income growth rates of energy surplus states to exceed those of energy deficit states. Several indirect consequences of higher energy prices may result in a reduction or elimination of surpluses and rents.

Energy-intensive industries may view adequate energy supplies as an important locational determinant. Proximity to such supplies will become a locational factor if transportation costs are a relatively large portion of total energy costs, as in the case of coal. Such inducements may result in a movement of industries from energy deficit states and large industrial centers toward energy surplus states [Miernyk 1976, p. 235; Giarratani and Socher 1978, pp. 103-116]. Obviously employment opportunities in the latter group of states would be enhanced.

Although energy company profits are likely to be widely diffused, higher energy prices may stimulate firms to reinvest heavily in energy surplus states, thereby increasing production and exploration capacity. A net effect of such behavior would be additional energy-related employment in energy surplus states and greater pressures for higher wages in energy extractive industries [Miernyk 1975, pp. 522-523].

Two further considerations of the reduction in consumers' surpluses and economic rents are important to Miernyk's hypothesis. Energy surplus states may derive increasingly larger shares of public revenues from severance taxes [Miernyk 1975, pp. 522-523] Three separate impacts may result. First, legislatures in these states may lower tax burdens of surplus states' residents. Lower tax burdens may then be employed as an inducement for firms to relocate in energy surplus states. Third, reliance on growing severance tax revenues by surplus states may result in fiscal decisions becoming relatively immune to cyclical volatility [Miernyk 1977, p. 3; Northeast-Midwest Coalition 1980].

Finally, the embargo of 1973-1974 helped accentuate the relative domestic abundance of coal. Coupled with reaction to the Three Mile Island accident and national policy mandates, electric generating facilities are now encouraged to rely more heavily on coal as a fuel source. An 
increased demand for coal and higher prices will shift income from highelectricity-consuming states to coal producing states [Miernyk 1976, p. 234].

Several of the above considerations might well be considered long run regional consequences of high energy prices. If that were the case, the period 1973-1977 would not be of sufficient length to test the effects of higher energy prices on real per capita income growth rates. A more likely short run response to higher energy prices would be employment and income stimulation in energy surplus states' energy sectors. State personal income growth will realize benefits from these developments if the respective states' energy sectors represent relatively high proportions of total state employment and income. Coupled with these ratios, relatively rapid post embargo growth rates of energy income and employment in energyrich states would lend strength to a confirmation of Miernyk's hypothesis.

Export base theory has been widely used as a foundation of regional economic growth. Essentially the theory is an extension of the law of comparative advantage, placing heavy emphasis on income flows into a region as a prime generator of economic growth. ${ }^{2}$ Several features of the export base theory appear pertinent in explaining growth rate differentials between energy surplus and energy deficit states, and thus, an export base model may provide a test of Miernyk's hypothesis.

Since energy resources are not equally distributed, states which possess such resources have a production advantage over states with less generous endowments. Obviously transportation costs limit the advantage [North 1955, p. 248 ]. However, in the case of most energy sources, technological advancements have served to minimize transport and distributional costs; e. g. long distance pipelines. (The advent of coal slurry pipelines may provide an alternative to current relatively high coal transportation costs.)

From the viewpoint of the state or region dependent on exports for sustained economic growth, external demand for its product(s) should be relatively price inelastic in the short run and not cyclically volatile [North 1955, pp. 250 and 252 ]. Energy surplus states would therefore be amenable to price inelasticity, for rising energy prices would result in higher revenues and greater income flowing into surplus states. ${ }^{3}$

Furthermore, export-led growth presumes that there exists a propensity to import [Tiebout 1956, p. 163]. Given the competitively low price of imported oil prior to 1973, refiners in states not generously endowed were more likely to import oil from foreign sources rather than import from other states. Concern over interruptions in the foreign flow of oil, the policy goal of energy independence, and efforts to keep domestic prices below world market levels would probably have increased the propensity of deficit states' refiners to import oil from other states after 1973.

Finally, factors of production in the exporting region would have to be relatively responsive to changes in export demands [Williamson 1975, pp. 3-4]. A result of such responsiveness would be an inflow of labor and capital into the exporting region, resulting in increased investment and reinvestment of profits locally earned, higher wages, and ultimately, enhanced economic growth. 
Most studies testing export base models investigate the relationship between export base employment and employment in tertiary sectors [Williamson 1975; McNulty 1977]. In a somewhat less common approach Luttrell and Gray [1970, p. 21] found a statistically significant positive relationship between the rate of growth of per capita income and the rate of growth of export base employment. A modified version of this model is employed to test Miernyk's hypothesis.

Export base employment was defined as state employment in the mining and manufacturing sectors. Obviously more state employment is dependent on exports than that restricted to these two sectors. However, mining and manufacturing employment tend to form the core of export base employment [Miernyk 1976, pp. 231-234]. Compound annual growth rates of each state's real per capita personal income and export base employment were calculated for the two periods, 1967-1972 and 1973$1977^{4}$ In an attempt to provide a more comprehensive accounting of state income growth rates, the compound annual growth rate of real capital expenditures in the mining and manufacturing sector of each state was included as an independent variable. ${ }^{5}$ To test Miernyk's hypothesis, data for all states in the two time periods were pooled into a linear regression equation, with the growth rates of export base employment and real capital expenditures designated as explanatory variables.

Modifications to the model consisted of including several dummy variables designed to capture shifts in the function's constant and possible interactions with export base employment and real capital expenditures. It was hypothesized that two forces would cause the function's constant to shift, time and regional influences. Conversely, it was hypothesized that these two influences would not result in a statistically significant interactive effect. The shift effect of time on the constant was specified as a dummy variable whose value equaled 1.0 if the observation occurred in the 1967 1972 period. Similarly, the regional effect on the constant was broadly specified by delimiting states into sunbelt and non sunbelt members. The dummy variable received a value of 1.0 if the state was a member of the former group. ${ }^{6}$

Chase Econometrics recently defined energy self-sufficiency as the ratio of energy production to energy consumption and calculated the ratio for all states in 1976. Energy surplus states were those whose energy production-to-consumption ratio exceeded 100.0 percent [Corrigan and Stanfield 1980, p. 469].7 Although deficiencies exist in the definition, such as inclusion of electricity consumption but not production, and no correction for domestic energy flows between states, it provides a more than arbitrary grouping of states with which to provide a test of Miernyk's hypothesis. Influence of the energy surplus dummy variable on the function was hypothesized to be through an interactive effect on the independent variables, export base employment growth and real capital expenditure growth. Furthermore, since the hypothesis is that higher energy prices are the cause of differential growth rates, the energy. surplus interactive effect was specified only for the post embargo observation of each energy surplus state. 
TABLE 1

Summary Growth Rates

(percent)

\begin{tabular}{|c|c|c|c|c|c|c|}
\hline \multirow[b]{2}{*}{ Group $(\mathrm{N})$} & \multicolumn{2}{|c|}{$\begin{array}{l}\text { Real Per Capita } \\
\text { Personal Income }\end{array}$} & \multicolumn{2}{|c|}{ Export Base Employment } & \multicolumn{2}{|c|}{ Real Capital Expenditures ${ }^{1}$} \\
\hline & 1967-1972 & $1973-1977$ & $1967-1972$ & $1973-1977$ & $1967-1972$ & 1973-1977 \\
\hline All States $(50)$ & 2.61 & 1.54 & .41 & .76 & -.32 & 7.37 \\
\hline Energy Surplus $(10)^{2}$ & 2.83 & 3.12 & 1.90 & 3.64 & -1.27 & 13.95 \\
\hline Energy Deficit $(38)^{3}$ & 2.48 & 1.34 & 2.83 & 1.80 & $-.15^{4,5}$ & $4.66^{4,5}$ \\
\hline Sunbelt (18) & 3.29 & 2.17 & 1.81 & .73 & $-.03^{4}$ & $7.52^{4}$ \\
\hline Energy Surplus (6) & 2.80 & 3.30 & 1.70 & 1.62 & -1.19 & 13.01 \\
\hline Energy Deficit (12) & 3.53 & 1.60 & 2.39 & .95 & $.60^{4}$ & $4.52^{4}$ \\
\hline Nonsunbelt (32) & 2.23 & 1.18 & -.37 & .77 & $-.47^{5}$ & $7.28^{5}$ \\
\hline Energy Surplus (4) ${ }^{2}$ & 2.89 & 2.85 & 2.46 & 5.61 & -1.38 & 15.36 \\
\hline Energy Deficit $(26)^{3}$ & 2.00 & 1.21 & 2.58 & 2.09 & $-.48^{5}$ & $4.71^{5}$ \\
\hline
\end{tabular}

${ }^{1}$ Mining and manufacturing.

${ }^{2}$ Excludes North Dakota.

${ }^{3}$ Excludes Utah.

${ }^{4}$ Excludes Maryland.

${ }^{5}$ Excludes Delaware. 


\section{EMPIRICAL RESULTS}

Prior to examining the results of the export base model, it would be helpful to review real per capita personal income, export base employment, and real capital expenditure performance for the major groups of states over the time periods considered. Table 1 contains the pertinent data.

When examining all states, real income growth rates were noticeably lower in the post embargo years. While energy deficit states experienced a slowdown of more than one percent on the average, energy surplus states registered a marginal acceleration in real income growth after the embargo. Sunbelt states' real per capita income outpaced that of the non sunbelt states in both time periods although both groups registered substantial declines over the entire period. Energy surplus states within sunbelt and non sunbelt regions experienced relatively constant or slight increases in real income growth rates after 1973. Deficit states, on the other hand, registered large declines in the same measure, as Table 1 indicates.

Few surprises emerged from the export base employment data. Energy surplus groups registered minor decreases or impressive gains. Energy deficit states, on the other hand, experienced noticeable slowdowns in export base employment growth after the embargo. The greatest margin of change occurred in non sunbelt surplus states; prior to the embargo this group of states registered an annual rate of growth of 2.5 percent in export base employment. Following the 1973 price surge, export base employment increased at an annual rate of 5.6 percent.

Rates of growth of real capital expenditures in mining and manufacturing illustrate remarkable differences prior to and after 1973. Every group of states except that of the sunbelt deficit registered negative growth rates prior to the embargo; each group experienced positive real growth in capital expenditures after the embargo. Closer examination reveals that each energy surplus group experienced greater real capital growth than the corresponding regional deficit group after the embargo.

Table 2 presents the results of the export base model designed to test Miernyk's hypothesis that energy surplus states' real per capita personal income growth rates significantly exceeded those of energy deficit states in the post embargo years. ${ }^{8}$ Results in Equation (1) confirm Luttrell and Gray's [1970] finding; export base employment growth was significantly correlated with real per capita personal income growth. The model in this paper was based on pooled cross sections; therefore, it would appear to lend credence to the appropriateness of export base models as explanations of long run regional economic growth [McNulty 1977, p. 365] Furthermore, the capital formation variable is statistically significant, lending an important dimension to the model and to Miernyk's hypothesis.

Mixed results surfaced from the inclusion of dummy variables in Equation (1). The pre embargo $\left(D_{1}\right)$ and sunbelt states $\left(D_{2}\right)$ dummy variables were statistically significant at the .05 level of confidence and both exerted a positive impact on state per capita real income growth. $D_{1}$ and $D_{2}$ confirm 
TABLE 2

Results of Export Base Model Tests $\dagger$

\begin{tabular}{|c|c|c|c|c|c|c|c|c|c|c|c|c|c|c|c|c|}
\hline & & & & & & & Vari & & & & & & & & & \\
\hline Equati & $\dagger \alpha$ & & $\mathbf{x}$ & & c & & $\mathrm{D}_{1}$ & & $\mathrm{D}_{2}$ & & $\mathrm{D}_{3} \mathrm{x}$ & & $\mathrm{D}_{3} \mathrm{C}$ & $\mathbf{R}^{2}$ & $\mathrm{Se}$ & d.f. \\
\hline (1) & .881 & + & $\begin{array}{c}.135 \\
(2.740)^{*}\end{array}$ & + & $\begin{array}{c}.048 \\
(2.013)^{*}\end{array}$ & + & $\begin{array}{c}1.405 \\
(5.884)^{*}\end{array}$ & + & $\begin{array}{c}.652 \\
(3.079)^{*}\end{array}$ & + & $\begin{array}{c}.021 \\
(.153)\end{array}$ & + & $\begin{array}{c}.065 \\
(1.368)\end{array}$ & .544 & .947 & 89 \\
\hline (2) & .867 & + & $\begin{array}{c}.125 \\
(2.554)^{*}\end{array}$ & + & $\begin{array}{c}.059 \\
(2.603)^{*}\end{array}$ & + & $\begin{array}{c}1.404 \\
(5.851)^{*}\end{array}$ & + & $\begin{array}{c}.710 \\
(3.409)^{*}\end{array}$ & + & $\begin{array}{c}.175 \\
(2.096)^{*}\end{array}$ & & & .534 & .951 & 90 \\
\hline (3) & .883 & + & $\begin{array}{c}.137 \\
(3.011)^{*}\end{array}$ & + & $\begin{array}{c}.048 \\
(2.019)^{*}\end{array}$ & + & $\begin{array}{c}1.404 \\
(5.914)^{*}\end{array}$ & + & $\begin{array}{c}.645 \\
(3.141)^{*}\end{array}$ & & & + & $\begin{array}{c}.071 \\
(2.521)^{*}\end{array}$ & .544 & .941 & 90 \\
\hline
\end{tabular}

fUtah and North Dakota not included.

†Dependent variable is the compound annual growth rate of real per capita personal income; calculated t-statistics in parenthesis.

*Statistically significant at the .05 level of confidence. embargo period; $D_{2}=1$ if state was classified as a sunbelt state; $D_{3}=1$ if state was in the energy surplus category and the observation was that of the post embargo period. 
TABLE 3

Differential Constants and Slopes'

Coefficients for Equations (2) and (3)

\begin{tabular}{|c|c|c|c|c|}
\hline \multirow[t]{2}{*}{$\begin{array}{c}\text { State Characteristics and } \\
\text { Time Period }\end{array}$} & & \multirow[t]{2}{*}{$\begin{array}{l}\text { Differential } \\
\text { Constant }\end{array}$} & \multicolumn{2}{|c|}{$\begin{array}{l}\text { Differential } \\
\text { Slopes }\end{array}$} \\
\hline & & & $\mathbf{x}$ & $\mathrm{C}$ \\
\hline $\begin{array}{l}\text { Pre Embargo, Non Sunbelt, } \\
\text { Energy Deficit }\end{array}$ & $\begin{array}{l}\text { Eq. (2) } \\
\text { Eq. (3) }\end{array}$ & $\begin{array}{l}2.271 \\
2.287\end{array}$ & $\begin{array}{l}.125 \\
.137\end{array}$ & $\begin{array}{l}.059 \\
.048\end{array}$ \\
\hline $\begin{array}{l}\text { Pre Embargo, Non Sunbelt, } \\
\text { Energy Surplus }\end{array}$ & $\begin{array}{l}\text { Eq. (2) } \\
\text { Eq. (3) }\end{array}$ & $\begin{array}{l}2.271 \\
2.287\end{array}$ & $\begin{array}{l}.125 \\
.137\end{array}$ & $\begin{array}{l}.059 \\
.048\end{array}$ \\
\hline $\begin{array}{l}\text { Pre Embargo, Sunbelt, } \\
\text { Energy Deficit }\end{array}$ & $\begin{array}{l}\text { Eq. (2) } \\
\text { Eq. (3) }\end{array}$ & $\begin{array}{l}2.981 \\
2.932\end{array}$ & $\begin{array}{l}.125 \\
.137\end{array}$ & $\begin{array}{l}.059 \\
.048\end{array}$ \\
\hline $\begin{array}{l}\text { Pre Embargo, Sunbelt, } \\
\text { Energy Surplus }\end{array}$ & $\begin{array}{l}\text { Eq. (2) } \\
\text { Eq. (3) }\end{array}$ & $\begin{array}{l}2.981 \\
2.932\end{array}$ & $\begin{array}{l}.125 \\
.137\end{array}$ & $\begin{array}{l}.059 \\
.048\end{array}$ \\
\hline $\begin{array}{l}\text { Post Embargo, Non Sunbelt, } \\
\text { Energy Deficit }\end{array}$ & $\begin{array}{l}\text { Eq. (2) } \\
\text { Eq. (3) }\end{array}$ & $\begin{array}{l}.867 \\
.883\end{array}$ & $\begin{array}{l}.125 \\
.137\end{array}$ & $\begin{array}{l}.059 \\
.048\end{array}$ \\
\hline $\begin{array}{l}\text { Post Embargo, Non Sunbelt, } \\
\text { Energy Surplus }\end{array}$ & $\begin{array}{l}\text { Eq. (2) } \\
\text { Eq. (3) }\end{array}$ & $\begin{array}{l}.867 \\
.883\end{array}$ & $\begin{array}{l}.300 \\
.137\end{array}$ & $\begin{array}{l}.059 \\
.119\end{array}$ \\
\hline $\begin{array}{l}\text { Post Embargo, Sunbelt, } \\
\text { Energy Deficit }\end{array}$ & $\begin{array}{l}\text { Eq. (2) } \\
\text { Eq. (3) }\end{array}$ & $\begin{array}{l}1.577 \\
1.528\end{array}$ & $\begin{array}{l}.125 \\
.137\end{array}$ & $\begin{array}{l}.059 \\
.048\end{array}$ \\
\hline $\begin{array}{l}\text { Post Embargo, Sunbelt, } \\
\text { Energy Surplus }\end{array}$ & $\begin{array}{l}\text { Eq. (2) } \\
\text { Eq. (3) }\end{array}$ & $\begin{array}{l}1.577 \\
1.528\end{array}$ & $\begin{array}{l}.300 \\
.137\end{array}$ & $\begin{array}{l}.059 \\
.119\end{array}$ \\
\hline
\end{tabular}

that pre embargo growth rates were significantly higher than those of the post embargo period and sunbelt states experienced growth rates in both time periods which were significantly higher than those of nonsunbelt states in the respective periods.

While interest in the above two dummy variables is legitimate, this paper's prime concern is with the interaction terms, $D_{3} \mathrm{x}$ and $\mathrm{D}_{3} \mathrm{c}$. Whereas $\mathrm{D}_{1}$ and $\mathrm{D}_{2}$ were specified to capture shifts in the model's constant, the interaction variables, $\mathrm{D}_{3} \mathrm{x}$ and $\mathrm{D}_{3} \mathrm{c}$, were designed to capture changes in the respective slopes of the model's independent variables. Neither interaction term was statistically significant in Equation 1 .

Upon examination of the raw data, it appeared that the interaction terms may be highly correlated, thus injecting bias into the standard errors of $\mathrm{D}_{3} \mathrm{C}$ and $\mathrm{D}_{3} \mathrm{x}$. Indeed the simple correlation coefficient between $\mathrm{D}_{3} \mathrm{C}$ and $\mathrm{D}_{3} \mathrm{x}$ was $.88 .{ }^{9}$ The equation was, therefore, reestimated twice. Each time 
one or the other affected interaction variables was excluded. As expected each interaction variable was statistically significant and positive (see equations 2 and 3.) Furthermore, the other independent variables retained their significance levels and hypothesized positive signs.

The magnitude of changes in the respective differential constants and slope coefficients based on the time period and state characteristics is illustrated in Table 3. Post embargo growth rates were, on the average, 1.4 percentage points lower than those of the pre embargo period. In addition sunbelt states' growth rate was approximately .65 of a percentage point higher than that of non sunbelt states. On the other hand, the impact of post embargo export base employment growth rates on real per capita income growth rates in energy surplus states was more than twice as great as the impact in energy deficit states; the capital expenditure interactive effect was three times larger in the energy surplus states as in the energy deficit state counterparts.

\section{CONCLUSIONS}

An effort was made in this paper to incorporate into a variant of the export base model Miernyk's hypothesis that post embargo energy prices caused real per capita personal income in energy surplus states to increase more rapidly than in energy deficit states. Dummy variables which distinguished post embargo years from the pre embargo period and sunbelt states from non sunbelt states exhibited positive statistically significant regression coefficients. As these two dummy variables were specified, they caused the regression equations' constants to shift upward.

The export base model provided a confirmation of Miernyk's hypothesis. Energy surplus states experienced considerably higher export base employment and real capital expenditure growth rates in post embargo years than energy deficit states. Furthermore, of the two components of export base employment, mining and manufacturing, the former realized larger gains, particularly after energy prices accelerated and in the energy surplus states. Dummy variables designed to capture the interaction of energy surplus membership in the period of higher prices with export base employment growth and real capital expenditures exhibited the hypothesized signs and were statistically significant. The key hypothesis tested was, therefore, confirmed.

The static nature of the model employed in this paper precludes capturing all of the influences important in regional economic growth. It does, however, lend credence to Miernyk's hypothesis. Through the export base mechanism, higher energy prices are likely to contribute to relatively rapid rates of income growth in states generously endowed with energy resources. While these results generally support the Miernyk hypothesis, it should be noted that income growth in most energy surplus states includes a heavy influence from pre embargo trends. In western states coal development responded to EPA sulfur emission regulations and an expanding export market. In the Southwest a well-developed intrastate energy 
market and an expanding manufacturing sector helped insulate the region from external shocks brought on by the embargo. However, it is likely that higher energy prices have complimented income growth from earlier trends in these areas.

\section{FOOTNOTES}

${ }^{1}$ Much of the survey of Miernyk's hypothesis is drawn from Manuel [1982, pp.9-10] and sources cited therein.

${ }^{2}$ Excellent surveys of the theory and of several empirical tests appear in Williamson [1975] and McNulty [1977].

${ }^{3}$ Own-price elasticity estimates for regions of the United States are presented in Allen [1977] Although there are wide regional differences in these estimates, all are well below unity.

${ }^{4}$ The GNP Implicit Price Deflator $(1972=100)$ was used to deflate all state per capita personal income estimates.

In a time series study of economic growth in Hawaii, Ghali [1973] employed a similar model with considerable success. Data on capital expenditures [U.S. Department of Commerce] were deflated using the nonresidential fixed investment component of the GNP Implicit Price Deflator $(1972=100)$.

${ }^{6}$ States defined as sunbelt members were Alabama, Arizona, Arkansas, California, Florida, Georgia, Kentucky, Louisiana, Maryland, Mississippi, New Mexico, North Carolina, Oklahoma, South Carolina, Tennessee,
Texas, Virginia, and West Virginia [Weinstein and Firestine 1978]

${ }^{7}$ Energy surplus states in 1976 were Alaska, Kansas, Kentucky, Louisiana, Montana, New Mexico, North Dakota, Oklahoma, Texas, West Virginia, and Wyoming [Corrigan and Stanfield 1980, p. 469].

${ }^{8} \mathrm{Utah}$ and North Dakota were not included in the data base to test the model. Chase Econometrics' energy production-to-consumption ratio for Utah was 100.0 percent and its highest share of national fossil fuel production was in coal, 1.24 percent in 1977. Utah's role as an energy surplus or deficit state is ambiguous at best. North Dakota met the tests of an energy surplus state. Manuel [1982, p. 18] found that North Dakota's rapid compound annual rate of growth of per capita personal income in the 1967-1972 period and its relative stagnation in the post embargo years was due to heavy dependence on the agricultural sector and the run up in wheat prices in 1972 and 1973.

${ }^{9}$ Employing a t-distributed test statistic to determine if the partial correlation coefficient between $D_{3} x$ and $D_{3} C$ was significantly different from zero confirmed the suspicion of collinearity [Murphy 1973, p. 381]

\section{REFERENCES}

Allen, B. J. 1979. The Integrating Model of the Project Independence Evaluation System. Vol. VI - Data Documentation, Part I. Washington: U. S. Department of Energy (February).

Corrigan, R. and R. L. Stanfield. 1980. "Rising Energy Prices - What's Good for Some States Is Bad for Others." National Journal (March 22): 468-474.

Field, B. C. and C. Grebenstein. 1980. "Capital-Energy Substitution in U. S. Manufacturing." Review of Economics and Statistics 63 (May): 207-212.

Ghali, M. 1973. "Exports, Investment, and Regional Growth," Southerm Economic Journal, 40 (October): 289-296.

Giarratani, F. and C. F. Socher. 1978. "The Pattern of Industrial Location and Rising Energy Prices." In Regional Impacts of Rising Energy Prices. W. H. Miernyk et al. Cambridge, MA: Ballinger Publishing Co.

Griffin, J. M. and P. R. Gregory. 1976. "An Intercountry Translog Model of Energy Substitution Responses." American Economic Review 66 (December): 845-857.

Kleinbaum, D. and L. Kuppert. 1978. Applied Regression Analysis and Other Multivariable Methods. North Scituate, MA: Duxbury Press.

Lakshmanan, T. R. 1981. "Regional Growth and Energy Determinants: Implications for the Future." Energy Journal 2 (April): 1-24.

Luttrell, C. B. and C. M. Gray. 1970. "Metropolitan Area Growth: a Test of Export Base Concepts." Federal Reserve Bank of St. Louis Review 52 (July): 8-24.

McNulty, J. E. 1977. "A Test of the Time Dimension of Economic Base Analysis." Land Economics 53 (August): 359-368.

Manuel, D. P. 1982. "The Effects of Higher Energy Prices on State Income Growth." Growth and Change 13 (July):26-37.
Miernyk, W. H. 1975. "Regional Employment Impacts of Rising Energy Prices." Labor Law Jourmal 26 (August): $518-523$.

1976. "Regional Consequences of High Energy Prices in the United States." Journal of Energy and Development 1 (Spring): 213-239.

1977. "Rising Energy Prices and Regional Economic Development." Growth and Change 9 (July): 2-7.

Mork, K. A. and R. E. Hall. 1980. "Energy Prices, Inflation and Recession." Energy Journal 1 (July): 31-64.

Murphy, J. L. 1973. Introductory Econometrics. Homewood, IL: Richard D. Irwin.

North, D. C. 1955. "Location Theory and Regional Economic Growth." Journal of Political Economy 63 (June): 243-258.

Northeast-Midwest Coalition. 1980. "The Effects of Rising State Severance Tax Revenues, 1980-1990." (April): mimeo.

Tiebout, C. M. 1956. "Exports and Regional Economic Growth." Journal of Political Ecomomy 64 (April): 160164.

United States, Department of Commerce, Bureau of the Census. Census of Manufacturing, and Census of Mineral Industries, 1967, 1972, 1977. Washington: U. S. Government Printing Office.

Williamson, R. B. 1975. "Predictive Power of the Export Base Theory." Growth and Change 6 (January): 3-10.

Weinstein, B. L. and R. F. Firestine. 1978. Regional Growth and Decline in the United States: the Rise of the Sunbelt and the Decline of the Northeast. New York: Praeger. 